\title{
SPRAWOZDANIE Z OGÓLNOPOLSKIEJ KONFERENCJI NAUKOWEJ, WARSZAWA NA PRZESTRZENI DZIEJÓW, (WARSZAWA, UKSW 18 LISTOPADA 2015 R.)
}

Dnia 18.11.2015 roku na Uniwersytecie Kardynała Stefana Wyszyńskiego w Warszawie odbyła się ogólnopolska studencko-doktorancka konferencja naukowa pt. „Warszawa na przestrzeni dziejów”. Miała ona miejsce na kampusie przy ul. Wóycickiego 1/3, w budynku nr 15, sali 1528. Jej organizatorem było Koło Naukowe Studentów Historyków UKSW.

Konferencja rozpoczęła się o godzinie 10:00. Obrady otworzył ks. prof. dr hab. Waldemar Graczyk, dyrektor Instytutu Nauk Historycznych UKSW. Przywitał on wszystkich prelegentów i życzył owocnych obrad.

Konferencja została podzielona na trzy części. Pierwsza z nich dotyczyła Warszawy jako miejsca odbywania sejmów i sejmików w epoce nowożytnej. Dwa pierwsze referaty, autorstwa mgr. Emila Kalinowskiego z UW i mgr. Macieja Pieńkowskiego z UKSW, zostały poświęcone właśnie temu drugiemu aspektowi. Mgr. Emil Kalinowski skupił się bardziej na sejmiku generalnym Mazowsza i Podlasia w latach 1569-1582, a mgr. Maciej Pieńkowski na sejmiku ziemi warszawskiej w latach 1661-1665. Trzecie wystąpienie, wygłoszone przez mgr. Marka Groszkowskiego z UKSW, dotyczyło głównie drugiego sejmu 1672 roku, który odbywał się właśnie w stolicy.

Druga część obrad była poświęcona życiu w Warszawie na przestrzeni dziejów. Otworzył ją mgr Bartłomiej Offerczak z UKSW. W swoim wystąpieniu skoncentrował się na rozwoju lokacji miejskiej miasta od XIII do XV wieku. Kolejny referat wygłosił Mateusz Tarasiuk z UW. Zaprezentował w nim rozwój gospodarczy Warszawy w drugiej połowie XIX wieku i jego wpływ na życie codzienne jej mieszkańców. Trzecią prelegentką była mgr. Marta Jastrzębowska ze Szkoły Wyższej Przymierza Rodzin w Warszawie. Skupiła się w szczególności na higienie w stolicy w latach 20 i 30 XX wieku. Panel zakończył mgr. Leszek Rysak z UKSW, który wygłosił referat pt. „Warszawa we i po wrześniu 1939 roku. Miasto i jego mieszkańcy".

Po przerwie obiadowej rozpoczęła się trzecia część obrad, poświęcona wizerunkowi Warszawy w kulturze. Otworzyli ją Maja Krasicka i Piotr Prawucki z Uniwersytetu im. Adama Mickiewicza w Poznaniu. Wygłosili oni referat pt. „Zburzyć - wybudować; spór o kształt stolicy w obliczu powojennych zniszczeń". Następne wystąpienie, autorstwa Małgorzaty Sobocińskiej z UAM w Poznaniu, było poświęcone podwójnemu obliczu miasta w fotografii Zofii Chomętowskiej z lat 1945-1946. Ostatni referat został napisany przez Joannę Kubacką z Uniwersytetu Łódzkiego. Niestety prelegentka nie mogła przybyć na obrady. Przysłane 
wystąpienie odczytał więc mgr Marek Groszkowski. Było ono poświęcone historycznej wizji stolicy w filmach (np. w „Mieście 44”) i w muzyce.

Obrady zamknął mgr. Marek Groszkowski, który dokonał też ich krótkiego podsumowania.

Po każdej części miała miejsce bardzo żywa dyskusja. Organizatorzy podziękowali wszystkim udzielającym się w niej osobom.

Wyrazy wdzięczności należą się też: prezesowi Koła Naukowego Studentów Historyków Kacprowi Szczęsnemu, a także sekretarz tej organizacji - Monice Annie Bożejko, za olbrzymi wkład w organizację omawianej konferencji. Olbrzymiej pomocy udzieliła również Fundacja Wyszyńskiego, która dostarczyła materiały konferencyjne, a także zabezpieczała przerwy kawowe. Dzięki firmie cateringowej „Willa Zagórze” prelegenci mogli otrzymać ciepły posiłek.

Podsumowując, można stwierdzić, ze konferencja pt. „Warszawa na przestrzeni dziejów” zakończyła się sukcesem, co zostało podkreślone przez ks. prof. dr. hab. Waldemara Graczyka, dyrektora INH UKSW. 